\section{A theory upon origin of implicit musical language}

\author{
József P. Vas \\ Psychotherapy Department, Borsod \\ University Hospital, Miskolc, Hungary
}

\begin{abstract}
The author suggests that the origin of musicality is implied in an implicit musical language every human being possesses in uterus due to a resonance and attunement with prenatal environment, mainly the mother. It is emphasized that ego-development and evolving implicit musical language can be regarded as parallel processes. To support this idea a lot of examples of musical representations are demonstrated by the author. Music is viewed as a tone of ego-functioning involving the musical representations of bodily and visceral senses, cross-modal perception, unity of sense of self, individual fate of ego, and tripolar and bipolar musical coping codes. Finally, a special form of music therapy is shown to illustrate how can implicit musical language be transformed into explicit language by virtue of participants' spontaneity, creativity, and playfulness.
\end{abstract}

\section{Introduction}

Why has man made musical instruments from human and animal bones, bowels, and skins since ancient times? Why is drumbeat experienced as having a charming effect a shaman gives rise when going into trance to reach spiritual worlds? And, why do we sense a peculiar crawly feeling in our bones while listening to xylophone playing? When playing an instrument a somatic resonance may emerge felt as a well-known experience from very early period of life, an experience from which nobody has conscious biographic memory. It is possible that impacts of music exerting on body and mind are capable to revive experiences stemming from fetal period. If it is the case one can raise a question whether music is viewed as a non-conscious implicit procedural memory of fetal experiences. ${ }^{1}$ If so, this implicit procedural memory may be expressed by implicit non-verbal musical language.

This paper does not serve to show philosophic and aesthetic theories of the origin of music. My idea is based upon results of developing psycho-neurobiology. I will consider those analogous processes and functions which can be treated as similar to both of fetal experiences and organization of music as a non-verbal specific language. The implicit language of music as a heritage of fetal life will be shown in the first part of the article. In the rest of the article it will be discussed on how inner mental processes, ego-functioning, and coping strategies, that is, regulation of ego-development can be represented in implicit musical language.

\section{The origin of musicality}

\section{Resonance and attunement into the world}

The ancient Greek principle of Panta rhei, that is, everything is in continuous movement, is now modified by quantum physics in a way that everything is in continuous resonance. ${ }^{2}$ On the one, physical levels of resonance as shown by laser-ray and hologram or harmony of sounds may be analogous to certain chemical, biological, and social phenomena. One can imagine a biophysical phenomenon, e.g. a receptor on the surface of an intelligent cell membrane to start to resonate or to dance when a hormone cocktail is just arriving. This hormone molecule has to be tuned in this resonance of the receptor to enter the cell. ${ }^{3}$ On the other, interpersonal attunement ranging from physical to spiritual levels can exist in all kind of human communities, in which the members' motivations, emotional attitudes, and aims can be viewed as the same, while means for realizing these aims are supposed as being accepted and available for everyone. ${ }^{4}$ This rule seems to be true of either being together of couples and families or being together of members of communities passing the time with ceremonial, artistic, and sport activities, let us think of a religious ceremony, a rock concert or a surgery team's cooperative work in an operating room. ${ }^{5}$

Neither instrumental nor vocal music could exist without resonance and tones. As a matter of fact, the whole universe is supposed to be full of resonance. ${ }^{6}$ In human life the first resonance is supposed to occur during conception between egg and sperm, then, between implanted embryo and cells of mother's endocrine glands. The cells of endocrine system contains inorganic piezoelectric crystals of nano-scale size by billions, capable of photon-emission. ${ }^{7}$ By creating a hologram, these might produce synchronous vibrations in groups of cells, in a whole organ, in the whole body at a quantum-wave level.8 Thus, a joint resonance and attunement between the mother and the embryo may be established since the beginning. It can be presumed that these synchronous vibrations might be responsible for producing energy fields of higher dimension surrounding the body - see the concepts
Correspondence: József Pál Vas, Psychotherapy Department, Borsod University Hospital, Szentpéteri kapu 72-76, 3526, Miskolc, Hungary. E-mail: nyelvmuhely.bt@upcmail.hu, vasjozsefpal@gmail.com

Key words: Musicality; prenatal resonance and attunement; musical representations of egodevelopment; musical coping codes.

Conflict of interest: the author declares no potential conflict of interest.

Received for publication: 19 September 2015. Accepted for publication: 26 November 2015.

This work is licensed under a Creative Commons Attribution NonCommercial 3.0 License (CC BYNC 3.0).

(C) Copyright J.P. Vas ., 2015

Licensee PAGEPress, Italy

Health Psychology Research 2015; 3:1932

doi:10.4081/hpr.2015.1932

of oriental healing, like chakras - which might constitute the basis of attunements among persons. ${ }^{9}$ How interesting is that tuning of energy-zones from deep to high sound frequencies are viewed as rising from $\mathrm{C}$ to $\mathrm{H}$ tone which can be accomplished by repeating mantras Sanskrit Wise Men said.10,11 We can say that we are attuned into the world. I suggest that this attunement into the world seems to be the most important basis of our susceptibility to music. Let us see what kind of other forms of attunement are available for us.

The friction of amniotic fluid on the surface of body - the first touching - provides a continual proof for the fetus of its existence. ${ }^{12,13}$ This fetal heritage represents the basis of any personal attunement, the state of being loved, or the state of sexual or emotional fusion. As a consequence, touching is said to be the mother of sense organs, and the primary and most important stimulus for developing central nervous system. ${ }^{14-16}$ As regarding hearing cochlea has already functioned since 8 days after conception by recent data. ${ }^{17}$ It is an astonishing result that 90 per cent of stimuli the fetus processes is accomplished by acoustic modality.18,19 Experiencing human voice is said to have a central role in fetal hearing. This viewpoint is supported by investigations in which infants could remember poems and songs they had already heard as fetuses. ${ }^{20,21}$ Attunement via interactional synchrony is viewed as one of the most crucial phenomena infants possess by virtue of mirror neurons, and adaptive oscillators when imitating mother's movements, mimics, and voices.22 We can come to the conclusion from mentioned above that resonance, touching, and hearing seem as the most fundamental energy processing a 
fetus possesses, by virtue of attunement established between the mother and the fetus. ${ }^{23-27}$

\section{Mother-fetus bonding and musicality}

According to research data of music psychology a fetus has already had musical susceptibility and skills. ${ }^{28}$ Processing of sounds and vibrations are accomplished by the fetal skin receptors before cochlea evolved. The effects of sounds a fetus senses are considered as fundamental sources of one's musical skills and talents, namely, sounds of mother's bodily functions. Such function may be the mother's heartbeat with a fluctuation in frequency according to breathing which can be the basis of tempo rubato in music. Other sounds in womb may be swish of blood, sounds from the mother's bowels and stomach, and those produced when mother eats and drinks. The mother's voice when speaking and singing seems to be prominent not only being as an acoustic experience but also being sensed by the fetus as a lot of stimuli which affect his/her inner state. The mother's breathing and walking rhythms, pauses, and the sound effects mentioned above can form a basis of melody, harmony, and rhythm. One cannot forget about amniotic fluid which conducts the sounds faster than air while emerging deep frequencies and overtones. We also enjoy this sounding bath in our adulthood without having a knowledge of its origin, e.g. when listening to rock music sitting in a speeding car. Physiological effects of music exerted on brain are divided into two parts: firstly, a hypnotic effect based on relaxation, and secondly, a hypnotic effect based on excitement and ecstasy. ${ }^{29}$ Especially, drumbeats with 4-6 c/s frequency can be regarded as rich in overtones to be suitable to activate tempolar lobe (4-6 c/s theta rhythm) producing trance state with visual and acoustic images. These characteristics can be viewed as physiological parameters of primordial rites accompanied with instrumental music, singing, and dancing.

Mother's heartbeats may be important resource of crucial signals as the mother's relaxing and exciting states are mediated to the fetus via her heart-rate variability which are reinforced and conditioned by hormonal message arriving form placenta just a little bit later. Since changes in the mother's heart-frequency is detected before arrival of hormonal message, the fetus will be capable to recognize emotional qualities of his/her mother's inner psychological state transmitted by this way. Can it be the reason why heart is considered as the center of emotions? Another question is whether our capacity for emotional anticipation depends on this intrauterine visceral communication. Salk, the famous pediatrician noticed that infants prefer the mother's left breast when sucking where they are more relaxed and fall asleep more quickly. It is not by chance that the infant Jesus is depicted on the Blessed Virgin's left arm by icon painters. ${ }^{21}$ One can understand that all melodies pacing smoothly with few oscillations in frequency of slow rhythm as reminding to heartbeat can be an implicit musical language of relaxation, love, peace, and inner contemplation. The fetuses are capable to process the deep frequencies of sounds only in the first half of pregnancy, and this might be the reason why bass serves as a basis of harmony and rhythm in every musical culture. Dynamik and Agogik - using German terms - seem as responsible for expressing emotional and timely features of melody which are patterns may be resulted from the mother's emotional prosody, dynamics, and physiological apnea. The pattern of these features are undoubtedly seen as equivalent to Stern's vitality affects. ${ }^{30}$ The fetus has probably the capacity to learn how to elicit musical experiences via movements of his/her own, to which the mother's visceral and kinetic response comes at any time. Would this interaction be regarded as an origin of developing emotional communication and interpersonal relationships of music? One can have every reason to believe that the origin of harmony, polyphony, and common musical activity stem from the prenatal period as a totality of vibration, vestibular, acoustic, kinesthetic, touching, and visceral stimuli organized to getting into higher order by the developing nervous system.

What kind of developmental process can be responsible for that musical experience involving anxiety, aggressive impulses, loss, and hope? It is probably the birthing process with its four phases called Basic Perinatal Matrices by Stan Grof. ${ }^{31}$ Listening to this kind of music someone can relive all of negative emotions and impulses reminding him/her as an implicit procedural memory to his/her first struggle with being stuck and successful coping while the birthing process is symbolized by music. We are in need for tragic and sorrowful music as well since firstly, in order to gain cathartic experience, secondly, to repeat heavy life situations in an unconscious and symbolic form to be overcome.

\section{Mother-infant relationship and music}

After being born a lot of joint auditory games of the mother and the infant are necessary for evolving musicality in a way that they repeat motives mutually heard from each other sometimes without change, sometimes with a few modifications. This can be the basis on which intoned proto-rhythms are built up, then the infant's own compositions are produced. 32,33 There is a very interesting example to illustrate the previous statement with a piece of classical music, namely the second movement from Mozart's Es major Symphonia
Concertante K.364., in which two solo instruments a violin and a viola play as if taking questions and giving answers to each other, alternately. Returning to the infant, the rewarding mother speaks to use tender and melodic declamation to her infant in a comforting way if (s)he is excited. This way the infant acquires the knowledge how to regulate own affective and motor discharges using the mother's speaking voices first of all. ${ }^{34}$ Winnicott has a nice idea about a homelike environment symbolically as a mother which can hardly be regarded as a human being, contrarily, it is a place where we enjoy ourselves since impressions we have had about it are attuned to our needs for security and being calm. ${ }^{24}$ Music can be a representation of such maternal environment when being surrounded and comforted by it.

To sum up I think of a musical idiom or an implicit musical language has to be existed similar to speaking idiom since the fetus has a perfect knowledge of this sort of musical capacities organized by intrauterine experiences and activities. Everybody needs musical idiom because it is capable to supply us with a musically symbolized mother-fetus bonding of attunement and unity, a feeling of omnipotence and a successful coping of birthing process even if it was through a toil-some struggle for life.

\section{Music as a tone of ego-func- tioning}

\section{A mutual attunement of physiolog- ical and emotional functions}

The intrauterine world's sounding panora$m a$ is likely to contribute to our mental apparatus and processes to be evolved since a lot of information of vital importance are mediated through this phenomenon about being in calmness, love, security, and about dangers threatening fetus, just as processes between the mother and the fetus becoming unbalanced and then reconstructed. In a case of danger the mother's heart-frequency will increase because of adrenalin release affecting the fetus as well. This may be the reason why listening to music of fast rhythm, especially with strong drumbeats may result in increasing heartbeats via an excitement of autonomous sympathetic nervous system. Would one think of music such as a media mirroring of ways of self-regulatory processes occurring in our mind?25 Might music include in certain patterns of those sounding and rhythmic processes which can symbolically be viewed as functions of our inner mental regulations? May music be a way as how a sensory stimulus coming from either outside or inside becomes a sense, a feeling, a motivation, an 
automatic motor or visceral response, an emotion, and finally, an evaluated emotion, that is, a conception?35

The essence of musical experience seems as an emotional synchronization between outer and inner realities probably based upon the attunement of physiological functions between the mother and the fetus. In the course of ego-development a symbolization process will be built up onto this physiological attunement. Either a recollection of unbearable emotions caused by serious conflict situation between the parents become fused with a physiological state of inner arousal or a recollection of calm felt when someone was accompanied by a loving person will be the representation of being in security. Thus, music seems as a sounding representation of our experiences and emotions. ${ }^{36}$ Listening to and playing music gives a possibility for our unconscious unbearable and joyful drives and sensations projected into the music itself in order to be revived, coped with, and sublimated. 37 The unconscious projection might result in reliving one's inner emotions as if being in the music only, not in the person's mind. Everybody knows people who switch off classical music heard in the radio saying that they don't understand this type of music, instead they might feel troublesome mainly, because of being over-excited for implicit procedural memories music recollects from early life experiences of their own. This also supports the legitimacy of theorizing implicit musical language.

While enjoying music the order of being in the world changes, one will be open while selfboundaries become blurred, either expanded or narrowed down immensely by virtue of synchronization of inner and outer realities. Being inside in expanded self-boundaries one can fly on the wings of feeling of omnipotence towards infinity with Beethoven's and Schiller's words in Ode to Joy: You millions, I embrace you. This kiss is for all the world! In one word the music facilitates both to elaborate unbearable emotions and to enrich egoexperiences through the necessary modification of self-boundaries resiliently reorganized. Meanwhile boundaries between outer and inner worlds become blurred an altered egofunctioning and state of consciousness, that is, trance state occurs, consequently. This seems as more obvious fact if ancient and modern ritual music is taken into consideration than in the case of passive listening to music (see: a primordial tribe's ceremony and a today's rock concert). Nevertheless, signs of trance state are seen and experienced in the latter case, too. Attention becomes getting focused on the music listened to being suitable to a sort of self-hypnotic trance, then an emotional attunement with strong affective fluctuation comes about. 38 Unconscious processes become accessible, and the person sinks into regres- sion. Primary processes with primitive drives, desires, fantasies, images, and symbols prevail, meanwhile rational thinking and reality orientation decrease, and suggestibility facilitating a state of ego-receptivity increases which is viewed as an ego-setting with increased susceptibility to stimuli, and a contemplative attitude. ${ }^{39}$ Definitely besides effects of enhancing activity and building relationships the easier accessibility of primary processes and regression in the service of the ego are regarded as such effects of music which is raising more attention to use in healing practice and for aims of health psychology and well-being recently. ${ }^{40,41}$

Consequently, music facilitates processes in the right hemisphere as an attunement between mind and body, moreover, among musicians' mental and bodily functions. ${ }^{42}$ As every form of arts the music is also considered as a regression in the service of the ego for the person's conscious efforts be withdrawn from daily obligations and fights into the secure world of fantasy, where (s)he can get relaxed, can refill with energy, and can test his/her own capacity for coping with symbolic dangers stemming from the outside or the inside without any challenges. Using music for this aim is reminding to myths of origin since both of them means a returning to the time of original being, to the Golden Age of freshness and wholeness. ${ }^{43}$ Both of them recollects an implicit memory with symbolic experiences of prenatal period of life, firstly, feelings of happiness, calm, security, and love, secondly, feelings of anxiety, rage, loss, and sorrow being analogous to the experience of being born. Nobody can forget that giving birth in a natural way means the most prominent and successful coping process in our life which pattern becomes coded into mental and bodily functioning. It is said by Zoltán Kodály that music doesn't respect frontiers relating as an universal and understandable language for all people in the world. ${ }^{44}$ Undoubtedly, music is a form of nonverbal but emotional communication mediating messages. Having the feature of immensity music is characterized not only in the sense of existing before verbal language but also on the basic quality of musical experience. Sound as a physical phenomenon spreads in the air, water, and solid. Thus, music as an acoustic stimulus enters the human body not only through the ears but through the bones, e.g., head, and caves full of air, e.g. chest and stomach, and fluid e.g. heart as well, contrary to say visual stimuli. It really doesn't respect the boundaries of the body. It becomes understood why one can hear music from inside and outside, synchronously. The outer and inner localization of musical experience at the same time can be due to a specialty of the mother-fetus bonding. It is since the mother's body can be considered as outer or inner depending on where the reference of viewpoint is. If it is referred to the fetus, the mother's body will be an outer reality, and in the case of referring to the environment the mother's body will be an inner reality.

Vibration of sounds results in meaningful physiological changes. During listening to music one can experience emerging excitements in the body when rhythm is sensed as an inner beating, and melody is experienced as if flowing in the heart meanwhile one can feel anxious, sad or pleasant and released, music can give power, it can make somebody move from beating time with a leg to beginning of dancing. In addition to be a cyclic change of excitement and relaxation the powerful effects of sounds with deep frequency and certain intensity on physiological functions are well-known. Drumbeats can accelerate heart-frequency, this effect is always used to increase temper to battle since ancient times.

\section{Organizing bodily senses in music}

Instructions for interpretations of some composition relates to triggering physically sensed bodily experience directly, for example grave which means gravely. Nevertheless, experiencing both physical and psychological effects directly by listening to and playing music seems to prevail at the same time. It is well-known that the composer's instructions relating the mode of interpretation, intonation, dynamics, beats, and orchestration of a composition utilize physical effects mentioned above. For this reason music is capable to transmit to the players and the listeners such bodily experiences as running, elevation, stopping short, and fall. 45 These seem to be equivalent to vitality affects, that is, certain functional modes of emerging sense of self presenting special forms of processing and characteristic patterns of activation of mind-body functions stem from an interaction inside motherinfant unit. ${ }^{46,47}$ Since the concept vitality affect means vital force and liveliness it is fit to the life-functions or liveliness of music as the same way as to the functioning of emerging sense of self as organizing its experiences. All of dynamics of music and the way as each musical tone, rhythm, intensity, and timing are interpreted can be viewed to be in analogy with vitality affects. One can think of Mozart's and Haydn's several musical grimaces in their Scherzo movements or some of Beethoven's and Wagner's inpatient or enraged musical gestures. Consequently, it is obvious that reviving bodily experiences in music can be viewed as a primary task for musical experience organized in the listener. This task sometimes may be conscious, sometimes may be pre- or unconscious for the composers and interpreters.

Organization of musical experience seems 
as an analogous process as evolving mature ego-functions from bodily ego. I suggest the idea that music is likely to participate somehow for setting of regulatory functions of fundamental homoeostatic systems with balancing sympathetic and parasympathetic tones, and with organizing states of relaxation and activation, and with regulating waking states and altered states of consciousness since the fetal period.

In the course of receptive music therapy going on at Psychotherapy Department of Borsod University Hospital, where I work, I asked 64 patients suffering from anxiety and depressive disorders to listen to Johann Sebastian Bach's $C$ major Prelude from The Well-Tempered Clavier BWV 846 in the frame of a study. After having listened to the music they were asked to write on what kind of sense they experienced. Without any statistical analysis it came to light that 81 per cent of the responses referred to bodily sensations of which 74 per cent proved as positive and 26 per cent as negative. Half of the positive responses was designated as calm which could be interpreted as a direct effect of Bach's music exerted on the mind-body regulation of depressive and anxious patients. ${ }^{26}$ This result supports the effective using of music for recovery of patients suffering from different illnesses in accordance with a new trend in health psychology. 48

\section{Organizing visceral quality of sens- es in music}

Typical examples of musical imitation symbolically expressing a somatic function can be cited sigh and heartbeat motives. Listening to Et incarnatus est movement from JS Bach's $H$ minor Mass a sigh falls as an almost weightless fluff similar to a holding one's breast. We can be witnesses of the mystery of incarnation of Holy Ghost embodied in an earthly woman named the Blessed Virgin illustrating how soul becomes a living body's sigh. On the contrary, we can listen to a sigh intoned by violins to rise in Lacrimosa from Mozart's Requiem indicating both sorrow of dead' relatives left behind and a rising of dead' soul.

Many of musical illustrations of heartbeat exist. Tears and sorrow are represented in the form of heartbeat imitated by cello pizzicato in Erbarme dich an alto aria from JS Bach's Matthew Passion which can be heard when Peter denies Jesus three times and suddenly realizing this he begins to cry bitterly. How easy feeling we feel while listening to the duet of Papageno-Papagena in the second act of Mozart's opera The Magic Flute. A nice pit-apat of orchestral introduction intoned by the strings can be a representation of heart's joyful quiver to find each other's double. In the finale of the first act of Mozart's comic opera Cosi fan tutte the two heroes attempt a false suicide for loving blackmail. We really don't know if comedy might change into tragedy or not, when listening to unison syncopations of violins - like somewhat irregular arrhythmia - which can anticipate cardiac arrest and vicinity of death. Another example is in the third act of Wagner's music drama titled as Tristan und Isolde. The deadly wounded Tristan's state is intoned as similar way as in the Mozart's Cosi fan tutte with the instruction to play diminuendo, that is, to play getting slowly with more and more pauses symbolizing a faint breathing and an interrupted functioning of heart. As if a flame of candle which is ready to be extinguished, it drops out again and again, and it will be stillness and darkness for a moment, then the flame will be revived in a scarcely discernible way.

One of the finest piece of Johann Sebastian Bach's heartbeat-music is the Air movement from the 3. D major Orchestral Suite. Calm and timelessness flows along with an almost infinite melody above basso continuo with $40 \mathrm{c} / \mathrm{s}$ frequency characterized by cerebral theta waves, a physiological correlation of relaxation, meditation, and zazen states. Researching correspondences between heartfrequency and perception came to light that in the course of effortless perception, that is, in the case of pure sensory input, a predominance of parasympathetic tone prevails with decelerating heart-frequency. ${ }^{49}$ While listening to Bach's music one really can get to the state of contemplation, a state of calm and harmony in which (s)he can become susceptible to have a feeling of infinity.

\section{Cross-modal perception in music}

Cross-modal perception means infants' inborn capacity to transmit visual, acoustic, kinesthetic, olfactory, touching, and gustatory experiences to whatever sense of modality, e.g. smell of breast-milk, that is, on the base of an olfactory sense (s)he is able to construct the taste of breast-milk (gustatory modality) or the mother's visual image (visual modality). It is as if neonates could possess an universal mode of perception before a perfect Babel of different sensing modalities named as amodal perception which can be translated into the specific modality of all senses. One can say without exaggeration that amodal perception - a perception without perception - plays a crucial role of creating aesthetic experiences, see poetic images. ${ }^{50}$

Music is defined as an acoustic phenomenon, however, it can't be considered as such only since it has all the qualities of emotions and pictures. To support this idea excellent examples can be cited as Vivaldi's, Beethoven's, Schubert's, Schumann's, Mendelssohn's, Wagner's, Mahler's, Debussy's, Respighi's, Bartók's, etc. so-called naturemusic full of representations of visual images, e.g. Vivaldi's falling leaves in the movement of Autumn from The Four Seasons. It may also happen that the visual image is stylized by music to express an impression of a natural picture in question as in Debussy's first piece of his Nocturnes titled as Clouds. Who wouldn't feel that luxuriant smell flown that is symbolically represented by music either of the rockgarden from Bartók's Bluebeard's Castle or Stravinsky's Le Sacre du Printemps? In the same way nobody can forget either the smell of silver rose Sophie gets form Count Rofrano in the 2. scene of Der Rosenkavalier's second act composed by Richard Strauss or flower-waltz in the second act from Puccini's opera Madama Butterfly or the scene of flower-girls in the second act from Wagner's Parsifal. Fresh odor of woods and strings are spreading from Schubert's, Schumann's, and Mahler's naturemusic. What acrid taste has that phrase played by solo violin heard when eating fresh current in Puccini's Suor Angelica!

There are visionary music as Mahler's 2. and 8. Symphonies, and such ones which affect the listener's kinesthetic perception. Rising kinesthetic experience seems as the most important psychological impact of music. The two Mahler's Symphonies serve a rich collection of moving experiences represented by music. Listening to the last movements both of the 2. and 8. we can relive falling down of fallen angels, and rising to the high, and a turbulence of human bodies, and expanding and closing of space as if looking at Michelangelo's Last Judgment.

\section{Unity of sense of self in musical experience}

It is obvious that bodily senses become manifested in the experience of moving at a higher grade in the very moment when running will be battle, rising will be purification. In order that bodily senses be experiences of higher grade symbolic representations of bodily senses are necessary as a synthesis of environmental impressions and emotional processes in the course of ego-development leading to the unity of sense of self. ${ }^{51}$ Evolving sense of self makes possible for the infant both to be differentiated from others and his/her body, self-image, and actions experienced in a unity. When the unity of sense of self is experienced all of the infant's perceptions, attitudes, and actions will be attuned in space, time, intensity, and course. The musical equivalence of unity of sense of self seems to be a composition itself as a unity containing an inner structure of hierarchy of elements regarding arrangements in space (orchestration), time, and dynamics. Naturally, the written structure of music, e.g. sonata form, isn't as the same as the musical experience which involves tones as sensory associations having the characteristics of space, time, intensity, and course. 
The written language of music contains explicit symbols (see: score) which are conveyed in an implicit form by interpreted music. This implicit language of musical experience will be explicit again by virtue of musical knowledge of the interpreter and the listener but this is not the experience itself! On the contrary, the musical experience is present in an implicit form in the score and it may become explicit in the listener. A very rare concurrence of musical experience and knowledge is of Mozart's story when he listened to Allegri's polyphonic choir Miserere prohibited to be published by Vatican. Mozart noted down accurately after he had listened to it twice.

Returning the explicit musical language one can notice very interesting relationships between visual appearance of score and the musical experience. If looking at the score of $C$ major Prelude from JS Bach The WellTempered Clavier Volume 1. we can see the drawing of melody as starting from a deep tone and rising up to the top. The melody has a tendency of falling gradually down to the groundnote. It is as if the melody came to the light continually as a source from the earth to descend to the valley as a string. Would this be a symbol of experience of calm, security, and love in the womb? Since the womb is seen as the source of life the spring can be interpreted as a symbol of being born. ${ }^{2}$ As a matter of fact implicit message coded into score might be understood in many ways but the stability of Bach's art can bear such interpretations since it shines as a cut diamond depending on how its surface is illuminated by light.

\section{Individual fate concentrated into music}

A continuity of our sense of self, that is, a sensing of ourselves to be the same today and tomorrow as we were two years ago is of a fundamental preconscious experience. A sense of self regarding historical unity in musical experience means also the continuity as in egodevelopment for every composition has special character, style, form, structure, and intonation creating an unity. As an example we can take two forms of musical organization: rondo and variation. A returning sequence leading to the proposition which is already known can be noticed in both forms. In the case of rondo form a theme like a good fellow leads us towards getting new and new experiences while hearing again and again the original subject, alternately as illustrated by A-B-A-C-AD-A-...formula. So rondo being a cyclic form can be a representative of repeating theme in one's fate based on self-similarity principle as how one accurately reiterates the same emotional attitude, behavioral reaction, etc. in an unconscious way. Thus, rondo mirrors adequately implicit procedural memory characteristic to organizing experiences in the course of ego-development. However, the variation can be viewed as a continuous repeating and changing process as seen in life-cycles.

So to say, whatever composition has got representations of internal and external worlds, and an autonomous life and fate here not relating a response by audiences and critics. It comes to light with musical instruments, evolves, gets involved in conflicts and contradictions, weakens, and revives, then finally vanishes as every human being. And, all of this happens in our hearing in a moment slipping away in comparison with the span of our lifetime. Were it not for experiencing this concentrated fate nobody would listen to classical music! To listen to the second movement titled Arietta from Beethoven's latest Piano Sonata $0 p$. 111. is especially interesting from this perspective since one can experience a whole lifespan from being born to the end. In the last beats of Beethoven's musical farewell is depicted as how music becomes gradually immaterial floating before transcending into spirituality.

\section{Coping codes in music}

\section{Tripolar cycle as musical coping}

If one observes the order of movements of a Baroque Concerto (s)he will notice three parts of it e.g., the first movement can be signed as Allegro, the second is Andante or Adagio or Largo, and the final movement is Allegro or Presto. The first movement is ordinary fast and joyful written in major key, the second slow movement felt as sad written is minor key, while in the final movement written in major key the delight in life returns; see several concertos of Corelli, Albinoni, Vivaldi, Handel, and Bach. It is very interesting that joy, sadness, and joy are regularly followed in this succession which can mean as positivenegative-positive, a triplet of thesis-antithesissynthesis in philosophy. This type of musical order is present in the Song form - its formula is A-B-A - and it is consonant with a human neurobiological phenomenon of positive-negative-positive organization of inner states. It symbolizes an emotional sandwich or a code of emotional coping in which the negative state is placed between the two positive ones in order that the negative one e.g., sorrow, anxiety be overcome. 53

The basis of the three part arrangement of a music as a code of emotional coping is named by me as tripolar cycle characterized to be an essential form inherent in mother-child emotional interactions. ${ }^{54}$ One can imagine an example of mother-child interaction when first, the mother, and say the one year old child are happy since the child is ceaselessly running in the room (a positive state), then the child is punished by the mother because a vase is broken (a negative state), finally, the mother forgives, and harmony will be returned between them (the second positive state). The tripolar cycle may be considered as an effective coping code since it contains the second positive emotional state after the negative state has already been coped with in a successful way. It may be funny, however, this scene with the sequence of tripolar code can become an implicit procedural memory which is repeated in the same way during different stress and conflict situations in the course of the lifespan. Many of psychiatric patients - even those patients who suffer from psychosomatic and somatic illnesses - may be characterized by lacking the second positive emotional state relating their interactions. The effectiveness of using music containing the code of tripolar cycle is viewed as crucially meaningful because this type of musical experience can form a basis of creating new coping given them in the form of music therapy. From the viewpoint of self-psychology and medicine an employment of well-selected pieces of music is very important for several advances, e.g. for relieving pain. 55

\section{Bipolar cycle as musical coping}

This coping code is of double arrangement based on an analogy of how nature changes along with contrasting cosmic cycles as winterspring and darkness-lightness. If seeing human nature the contrasts can be such as gloomy-bright mood, yes-no, security-anxiety, chaos-order, death-revival, etc. The code of bipolar cycle based on contrasts involves the laws of Nature just as the lonely man faces the world. One of the most famous musical examples is the end of the 3. movement and the beginning of the 4 . of Beethoven's 5 . Symphony when the music of march characteristics gradually fades as if falling to nothingness. Only the timpani repeats the famous four tones, a rhythm of destiny. Suddenly the music becomes loud to start a triumphal march in $\mathrm{C}$ major. This is the Hero's motif who stands facing the world and his fortune. If employing this type of music we need to be careful to people's sensitivity to the extreme contrasts, and if it is the case, for example of patients suffering from terminal illness or unbearable pain it is necessary to use more subtle transitions from negative to positive emotional states conveyed by music.

\section{Resolving splitting of emotional states as a form of coping}

If contrasting emotions are mixed peculiar states can occur expressing joy and sorrow, anger and melancholy at the same time. A splitting between the two different states can be resolved this way with the predominance of the positive state which helps keep unbearable 
emotions as grief and sorrow. In an example of Mozart's $G$ minor Symphony 1. movement one can feel joy and a little bit grief synchronously as if one sang when being sad. Another excellent example is that of funeral march. The second movement from Beethoven's 3. Symphony can be considered as one of the most famous pieces. Here music also brings contradictory tendencies at the same time, firstly, a discontinuity of life relating dead, secondly, a continuity of life relating people alive. The splitting between the two states can be resolved by marching rhythm of music representing both a moving emotion and the moving as a start towards new possibilities of life.

\section{How implicit musical language can make explicit in a receptive group music therapy?}

I hold receptive music therapy groups as long as 90 minutes once a week at Psychotherapy Department where I work. Maximum 15 participants with mental problems can ask to be admitted in each therapy session to take part in this group's activity. The setting is as following: i) I talk about a piece of classical music then it is listened to by CD; ii) depending on the participants' number two or three sub-groups are created; iii) I ask the patients in each sub-groups to have a discussion in secret about what kind of story can be a representative of the next music, and how they want to play this story in the frame of a pantomime; iv) a 5-8 minute's long piece of classical music is played on CD (6-7 pieces of music are shown in a session); v) after having listened to this piece of music generally unknown for them the members of the first sub-group play the pantomime; vi) the members of the second sub-group have to unravel the meaning of the pantomime; vii) the second sub-group shows its own pantomime; viii) the first sub-group has to unravel the meaning of the pantomime the second sub-group performed.

In this group music therapy the participation is voluntary, the participants are not selected. The process contains to decode implicit musical language to an explicit verbal code, that is, to translate music into a story, and a newer transformation into a non-verbal kinesthetic language, a pantomime, then to recode an impression of this pantomime to verbal language again by the other sub-group. According to my experiences there are several attunements and synchronicities between the two or three sub-groups as they create similar stories and express the essence of music. For example, listening to Solveig's Song from Grieg's Peer Gynt Suite No.2, Op. 55, which music was unknown for the patients as they stated at the end of the session, all the three sub-groups produced a performance in which a woman was alone and sad, and she was waiting very much her husband or pair. Another example is also Grieg's An den Frühling from his Lyric Pieces Op. 43, No.6. After had been listened to it each of two sub-groups created similar stories and pantomimes, too. The first subgroup's production showed a man and a woman having found each other as a couple of love, the second sub-group performed a pantomime in which four women were flowers in the moments just opening slowly their petals while a man was nursing them.56 This kind of music therapy is very popular among the patients because it makes possible spontaneity, creativity, a moving experience, competition, joy, and playfulness for them. I have always been convinced of existing implicit musical language when I take part in these sessions of group music therapy.

\section{Conclusions}

Music is a media of healing soul and body in every period of cultures and history. It is capable to reflect disharmony and harmony the whole existence imbued with, and to mobilize resources both for achieving successful coping with disharmony regarding destiny and for restoring calm and harmony in human relationships. In addition to this, music is a subjective means of communication for altering people's conscious and emotional states rooted in being together as members of a community. To practice and use music for healing equals to do for people's well-being. It is possible that music as an implicit language is analogous to the unconscious neuropsychological functions processing in our mind. If so, music can be viewed as the nicest message of the implicit world. One can view it as a matrix by virtue of its embracing conflicts may be resolved and wild instincts become tamed when we walk through the realm of Hades as Orpheus did. Music is a holding environment and a promise. A promise of beauty, good, and hope. It springs from us. Be careful of it!

\section{References}

1. Vas JP. Experiencing music and Stern's theory upon developing sense of self. Pszichoterápia 1998;7:17-23.

2. Bohm D. Wholeness and the implicate order. London: Routledge \& Kegan Paul; 1980.

3. Pert CB, Marriott N. Everything you need to know to feel Go(o)d. Budapest: Édesvíz
Kiadó; 2007.

4. Vas JP. [Tones and being tuned. Suggestions upon common origins both of music therapy and hypnotherapy]. Psychiatr Hung 2013;28:159-64. [Article in Hungarian].

5. Bagdy E. Tone, movement, rhythm: intrauterine roots of psychic organization of musicality. In: Sound and soul. Proceeding of Conference Upon Music Education. Budapest: Hungarian Music Council; 2002. pp 43-51.

6. Combs A, Holland M. Synchronicity. Budapest: Édesvíz Kiadó; 1997.

7. Bókkon I. Visual perception and imagery: a new molecular hypothesis. BioSystems 2009;96:178-84.

8. Vas JP. Some thoughts upon unity of soul and body in the period of neuroscience. Pszichoterápia 2007;16:179-83.

9. Leskowitz ED. Energy healing and hypnosis. In: Leskowitz ED, ed. Transpersonal hypnosis. Gateway to body, mind, and spirit. New York: CRC Press; 2000. pp 25-38.

10. Chamberlain DB. Prenatal intelligence. In: Blum T, ed. Prenatal perception learning and bonding. Berlin: Leonardo Publishers; 1993. pp 9-31.

11. Chamberlain DB. Observations of behavior before birth: current findings. In: Klimek R, Fedor-Freyberg P, Janus L, Walas-Skolicka E, eds. A time to be born. Cracow: Dream Publishing Company; 1996. pp 61-73.

12. Blum T, ed. Prenatal perception learning and bonding. Berlin: Leonardo Publishers; 1993.

13. Veldman F. Confirming affectivity, the dawn of human life. Int $\mathrm{J}$ Prenat Perinat Psychol Med 1994;6:11-26.

14. Montagu A. Touching. The human significance of the skin. New York: Harper \& Row; 1986.

15. Heller S. The vital touch. How intimate contact with your baby leads to happier, healthier development. New York: Henry Holt \& Company; 1997.

16. Nyitrai E. Power of touch. Budapest: Kulcslyuk Kiadó; 2011.

17. Austermann AR, Austermann B. Drama in the Womb. Budapest: Hellinger Institute; 2008.

18. Fridman R. Proto-rhythms: music in prenatal and postnatal life. In: Blum T, ed. Prenatal perception learning and bonding. Berlin: Leonardo Publishers; 1993. pp 247252.

19. Gellrich M. Development of musicality before birth and in early childhood. In: Blum T, ed. Prenatal perception learning and bonding. Berlin: Leonardo Publishers;1993. pp 279-306.

20. Gilroy A, Lee C. Art and music: therapy and research. London, New York: Routledge; 
1995.

21. Janus L. The enduring effects of prenatal experience. London: Jason Aronson; 1997.

22. Whitehead C. Social mirrors and shared experiential worlds. J Conscious Stud 2001;8:3-36.

23. Pribram K. The holographic hypothesis of brain function. A meeting of minds. In: Grof S, ed. Ancient wisdom and modern science. New York: New York State University Press; 1984.

24 Ogden TH. The matrix of the mind. New York: Jason Aronson; 1986.

25. Stern DN. The present moment in psychotherapy and everyday life. New York: Norton; 2004.

26. Schore AN. Affect dysregulation \& disorders of the self. New York: W.W. Norton \& Company; 2003.

27. Vas JP. A psychiatrist's doubts. Thoughts upon psychotherapy. Budapest: ProDie; 2005.

28. Hanser SB. Music therapist's handbook. St. Louis: Warren H. Green; 1987.

29. Sekeles C. Motion and emotion. The developmental-integrative model in music therapy. Marceline (USA): Walsworth Publishing; 1996.

30. Stern DN. The interpersonal world of the infant. New York: Basic Books; 1985.

31. Grof S. The psychology of the future. New York: New York State University Press; 2000.

32. Bunt L. Music therapy. An art beyond words. London, New York: Routledge; 1994.

33. Feder S, Karmel RL, Pollock GH, eds. Psychoanalytic explorations in music. New York: International Universities Press;
1993.

34. Vas JP. Some ideas upon origins of musical capacity. In: Vas JP, ed. A psychiatrist's doubts. Thoughts upon psychotherapy. Budapest: ProDie; 2005. pp 428-450.

35. Siegel DJ. The developing mind. Toward a neurobiology of interpersonal experience. New York: The Guilford Press; 1999.

36. Rechardt E. Experiencing music. Psychoanal Study Child 1987;42:511-30.

37. Kohut H, Levarie S. On the enjoyment of listening to music. Psychoanal Quart 1950;19:64-87.

38. Watkins JG, Barabasz A. Advanced hypnotherapy. Hypnodynamic techniques. New York: Routledge; 2008.

39 Fromm E. Primary and secondary process in waking and in altered states of consciousness. J Altered States Consciousness 1978-79;4:115-28.

40. Wigram T, Saperston B, West R. The art and science of music therapy: a handbook. London: Harwood Academic Publishers; 1995.

41. Davis W, Gfeller KE, Thaut HM. An introduction to music therapy. New York: Wm.C. Brown Publishers; 1998.

42. Iñesta C, Terrados N, García D, Perez JA. Heart rate in professional musicians. $\mathrm{J}$ Occup Med Toxicol 2008;3:16.

43. Eliade M. Myth of eternal returning. Budapest: Európa; 1993.

44. Kodály Z. A zene mindenkié (Music is of everyone). Budapest: Zenemükiadó;1975.

45. Fink-Jensen K. Attunement and bodily dialogues in music education. Philosophy of Music Education Review 2007;15:53-68.

46. Stern DN. The motherhood constellation. New York: Basic Books; 1995.
47. Decker-Voigt HH. Zenével az életbe. A hangok szerepe a váradósság idején és a gyermekkorban. (Enter Life With Music. Roles of Sounds During Pregnancy and Childhood) Budapest: Medicina; 2004.

48. Sendelbach SE, Halm MA, Doran KA, et al. Effects of music therapy on physiological and psychological outcomes for patients undergoing cardiac surgery. J Cardiovascular Nurs 2006;21:194-200.

49. Noy P. How music conveys emotion. In: Feder S, Karmel RL, Pollock GH. eds. Psychoanalytic explorations in music. New York: International Universities Press; 1993. pp 125-149.

50. Parncutt R. Prenatal experience and the origins of music. In: Blum T, ed. Prenatal perception learning and bonding. Berlin: Leonardo Publishers; 1993. pp 253-277.

51. Beebe B, Knoblauch S, Rustin J, Sorter D. Forms of intersubjectivity in infant research and adult treatment. New York: Other Press; 2005.

52. Leuner $H$. Lehrbuch das katathymen Bilderlebens. Bern: H.Huber; 1985.

53. Vas JP. Establishing neuropsychoanalysis. Imago Budapest 2011;1/22:23-38.

54. Vas JP, ed. Musical coping codes. A psychiatrist's doubts. Thoughts upon psychotherapy. Budapest: ProDie; 2005. pp 452-461.

55. Cepeda MS, Carr DB, Lau J, Alvarez H. Music for pain relief. Cochrane Database Syst Rev 2006:CD004843.

56. Vas JP. Fortunes and motifs. Some ideas upon the meeting points of music therapy and hypnotherapy. Psychiat Hung 2013;28:291-9. 